\title{
Efektivitas Discovery Learning Model dengan Media Powerpoint Meningkatkan Hasil Belajar IPA SD
}

\author{
Ni Komang Atik Astiti ${ }^{*}$, Maria Goreti Rini Kristiantari ${ }^{2}$, Ketut Alit Saputra ${ }^{3}$ \\ ${ }^{1}$ Pendidikan Profesi Guru Prajabatan, Universitas Pendidikan Ganesha, Singaraja, Indonesia \\ ${ }^{2} J u r u s a n$ Pendidikan Guru Sekolah Dasar, Universitas Pendidikan Ganesha, Singaraja, Indonesia \\ ${ }^{3}$ Sekolah Dasar Negeri 4 Kampung Baru, Singaraja, Indonesia
}

\section{ART ICLE IN F O}

Article history:

Received May 10, 2021

Revised May 15, 2021

Accepted July 06, 2021

Available online August 25, 2021

Kata Kunci:

Discovery Learning, Powerpoint, Hasil Belajar

Keywords:

Discovery Learning, Powerpoint, Learning Outcomes

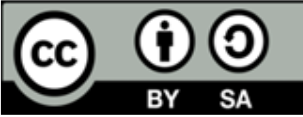

This is an open access article under the CC BY-SA license.

Copyright $(2021$ by Author. Published by Universitas Pendidikan Ganesho.

\begin{abstract}
A B S T R A K
Penelitian ini dilakukan karena hasil belajar IPA siswa kelas VI belum optimal. Hal ini disebabkan oleh pembelajaran yang dilaksanakan guru belum menggunakan model inovatif serta media pembelajaran yang dapat menumbuhkan antusias siswa dalam belajar. Penelitian ini bertujuan untuk meningkatkan hasil belajar IPA melalui penerapan discovery learning model berbantuan media powerpoint. Jenis penelitian yang digunakan adalah penelitian tindakan kelas. Subjek penelitian adalah siswa kelas VI sebanyak 33 orang. Pengumpulan data menggunakan metode tes berbentuk pilihan ganda dengan jumlah soal sebanyak 20 butir. Data hasil belajar dianalisis dengan teknik deskriptif kuantitatif yaitu dengan mencari rata-rata nilai siswa dan ketuntasan belajar. Hasil penelitian menunjukan pada siklus I rata-rata nilai hasil belajar mencapai 67,57 ketuntasan belajar mencapai 66,66\% dengan kriteria cukup dan pada siklus II mengalami peningkatan rata-rata nilai hasil belajar mencapai 79,84 dan ketuntasan belajar mencapai $87,87 \%$ dengan kriteria tinggi. Dapat disimpulkan adanya meningkatkan hasil belajar IPA siswa kelas VI melalui penerapan discovery learning model berbantuan media powerpoint
\end{abstract}

\section{A BS TRACT}

This research was conducted because the science learning outcomes of grade VI students were not optimal. This is because the learning carried out by the teacher has not used innovative models and learning media that can foster student enthusiasm in learning. This study aims to improve science learning outcomes through the application of discovery learning learning models assisted by powerpoint media. The type of research used is classroom action research. The research subjects were 33 grade VI students. The data collection used the multiple-choice test method with a total of 20 questions. Learning outcomes data were analyzed using quantitative descriptive techniques, namely by finding the average student score and learning completeness. The results showed in the first cycle the average value of learning outcomes reached 67.57 learning completeness reached $66.66 \%$ with sufficient criteria and in the second cycle the average value of learning outcomes reached 79.84 and learning completeness reached $87.87 \%$ with high criteria. It can be concluded that there is an increase in science learning outcomes for grade VI students through the application of discovery learning learning models assisted by powerpoint media.

\section{PENDAHULUAN}

Salah satu muatan pembelajaran yang dibelajarkan di sekolah dasar yang memiliki peranan cukup besar dalam pengembangan kompetensi siswa adalah muatan pembelajaran IPA. IPA merupakan salah ilmu yang mempelajari tentang fenomena alam dan segala sesuatu yang ada dialam. Pembelajaran IPA yang dilaksanakan dengan terpadu sangat bermanfaat bagi siswa, yaitu digunakan sebagai bekal dalam menyelesiakan permasalahan yang dihadapi dalam kehidupan sehari-hari (Agustami et al., 2017; Sappe et al., 2018). Sains atau IPA memiliki hubungan dinamis yang mencakup tiga faktor utama yaitu the extant body of scientific knowledge, the values of science and the method and procecces of science yang artinya sains merupakan produk dan proses, serta mengandung nilai-nilai (Eviani, Sri Utami, 2017; P. Putra, 2017b). IPA sebagai proses/metode penyelidikan meliputi cara 
berpikir, sikap dan langkah-langkah kegiatan scientis untuk memperoleh produk-produk IPA, misalnya observasi, pengukuran, merumuskan, menguji hipotesa, mengumpulkan data, bereksperimen dan prediksi (Supardi, 2017; Surya, 2017). Ketrampilan proses yang perlu dilatih dalam pembelajaran IPA meliputi ketrampilan proses dasar misalnya mengamati, mengukur, mengklasifikasikan, mengkomunikasikan, mengenal hubungan ruang dan waktu, serta ketrampilan proses terintegrasi misalnya merancang dan melakukan eksperimen yang meliputi menyusun hipotesis, menentukan variable, menyusun definisi operasional, menafsirkan data, menganalisis dan mensintesis data (Johana Ermina Setyaningtyas, Firosalia Kristin, 2018; Juita, 2019). Dengan demikian dapat disimpulkan bahwa ketrampilan proses dalam pembelajaran IPA di SD meliputi ketrampilan dasar dan ketrampilan terintegrasi. Kedua ketrampilan ini dapat melatih siswa untuk menemukan dan menyelesaikan masalah secara ilmiah untuk menghasilkan produk-produk IPA yaitu fakta, konsep, generalisasi, hukum dan teori-teori baru.

Pembelajaran IPA di sekolah dasar merupakan pondasi awal menciptakan siswa-siswa yang memiliki pengetahuan, keterampilan dan sikap ilmiah. IPA merupakan salah satu muatan pembelajaran pokok yang terdapat dalam kurikulum di Indonesia dan selalu diberikan pada setiap jenjang pendidikan sehingga IPA perlu dikembangkan dalam setiap proses pembelajarannya (Kusumah et al., 2020; Muyaroah, 2018). Pembelajaran IPA pada tingkat manapun harus dikembangkan. Pembelajaran IPA di SD meliputi ketrampilan dasar dan keterampilan terintegrasi (Jundu et al., 2013; Portanata et al., 2017). Kedua ketrampilan ini dapat melatih siswa untuk menemukan dan menyelesaikan masalah secara ilmiah untuk menghasilkan produk-produk IPA yaitu fakta, konsep, generalisasi, hukum dan teori-teori baru (Ichsan et al., 2018). Mengacu pada hal tersebut perlu diciptakan kondisi pembelajaran IPA di SD yang dapat mendorong siswa untuk aktif, selalu ingin tahu dan menemukan sendiri suatu konsep. Namun, siswa dalam mempelajari IPA hanya sebagai produk, menghafal konsep, teori dan hukum (Awe \& Benge, 2017; Putra, 2017). Akibatnya IPA sebagai proses, sikap dan aplikasi kurang tersetuh dalam pembelajaran.

Terdapat beberapa permasalahan dalam muatan pembelajaran IPA yang ditemui. Berdasarkan hasil observasi diperoleh bahwa nilai akhir semester siswa kelas VI pada muatan pelajaran IPA masih tergolong rendah dan belum mencapai hasil belajar yang maksimal. Rata-rata nilai kelas IV ulangan akhir semester I muatan pembelajaran IPA yaitu 70 dalam katagori cukup. Nilai belajar rendah diakibatkan oleh beberapa masalah diantaranya yaitu pertama model pembelajaran yang digunakan dalam kelas tersebut kurang inovatif, sehingga cenderung membuat siswa bosan dalam pembelajaran. Kedua media yang digunakan guru kurang menarik perhatian siswa. Ketiga keterlibatan siswa dalam pembelajaran sangat kurang. Siswa hanya mau aktif dalam pembelajaran ketika pembelajaran tersebut menantang untuk mereka. Dalam artian diselingi permainan atau kuis-kuis yang dapat menarik minat mereka terhadap pembelajaran. Maka terkait dengan hasil belajar IPA siswa dapat diidentifikasi beberapa masalah yaitu hasil belajar siswa kelas VI muatan pelajaran IPA masih tergolong rendah berdasarkan hasil ulangan yang diperoleh siswa, kurang bervariasinya model pembelajaran yang digunakan oleh guru pada saat proses belajar mengajar, sehingga hasil belajar muatan pelajaran IPA rendah, kurang adanya interaksi siswa dengan guru saat pembelajaran sehingga pembelajaran masih bersifat pasif, dan kurangnya penggunaan media dalam pembelajaran IPA yang dapat menarik minat siswa belajar.

Masalah tersebut juga sejalan dengan penelitian sebelumnya yang menyatakan bahwa lemahnya pelaksanaan proses pembelajaran IPA yang dilakukan oleh guru masih dilakukan secara konvensional (Frandy Pratama, Firman, 2010; Wahyuningtyas \& Sulasmono, 2020). Para guru belum sepenuhnya melaksanakan pembelajaran secara aktif dan kreatif dalam melibatkan siswa. Selain itu, dalam proses pembelajaran kebanyakan guru hanya terpaku pada buku teks sebagai satu-satunya sumber belajar mengajar (Sudana, 2018; Tias, 2017). Kebanyakan guru tidak melakukan kegiatan pembelajaran yang memperhatikan dimensi dari IPA dan tinggi rendahnya minat belajar yang dimiliki oleh siswa (Nugroho Widiantono, 2017; Nuraini \& Kristin, 2017). Hasil penelitian lain juga menyatakan masalah yang sama yakni dalam mengajar hanya menggunakan satu sumber belajar (Hujaemah et al., 2015; Ni Kt. Dewi Muliani, 2019). Hal tersebut akan mengakibatkan kemampuan siswa menjadi terbatas sehingga akan berdampak pada rendahnya hasil belajar IPA siswa dan sulit melibatkan siswa secara aktif dalam proses pembelajaran sehingga aktivitas siswa menjadi pasif. Guru memperkenalkan IPA hanya sebatas dimensi produk saja, dengan mengabaikan dimensi proses dan dimensi sikap ilmiah, dan siswa kurang dibiasakan bekerja dalam kelompok, sehingga terdapat kecenderungan yang pintar akan semakin pintar dan yang kurang akan semakin kehilangan kesempatan untuk mengembangkan kompetensi yang dimilikinya (Sitohang, 2017; Winantara, 2017). Ini disebabkan karena tidak adanya sharing pendapat atau diskusi terhadap suatu permasalahan. Jadi, penyebab hasil belajar siswa rendah salah satunya yaitu pembelajaran masih bersifat konvensional. Jika hal ini dibiarkan, maka hasil belajar IPA siswa tidak mengalami peningkatan. 
Permasalahan yang ada maka perlu dicarikan solusi yang tepat guna memperbaiki hasil belajar siswa. Solusi yang dapat diterapkan adalah dengan melakukan suatu penelitian tindakan kelas. Dalam pelaksanaan penelitian tindakan kelas diperlukan suatu model pembelajaran yang dapat mengatasi permasalahan permasalah diatas, untuk diterapkan dalam pembelajaran di kelas. Model pembelajaran yang cocok diterapkan dalam pembelajaran IPA adalah discovery learning model (belajar penemuan). Penerapan discovery learning model sebagai salah satu tipe model pembelajaran inovatif akan dapat memberikan pengalaman langsung yang bersifat konkret dalam penemuan yang dialami siswa secara langsung (Nugrahaeni, 2019; Nurrohmi et al., 2017). Dengan demikian, discovery learning model akan dapat menguatkan ingatan siswa terhadap materi yang dipelajarinya, karena pembelajaran yang dialami siswa dalam penemuan berfungsi sebagai tinjauan untuk memantapkan pemahaman siswa terhadap materi pembelajaran yang telah dipelajarinya sebelum siswa mengikuti tes individual. Menggunakan discovery learning model di kelas membantu guru untuk meningkatkan pemahaman dan motivasi di antara murid-murid yang diharapkan menghasilkan peningkatan motivasi dan prestasi jangka panjang (Oktaviani et al., 2019; Prasetyo \& Kristin, 2020). Oleh karena itu discovery learning model perlu diterapkan untuk mengatasi permasalahan hasil belajar.

Melalui model ini siswa diajak untuk menemukan sendiri apa yang dipelajari kemudian mengkonstruk pengetahuan itu dengan memahami maknanya. Dalam model ini guru hanya sebagai fasilitator. Ciri utama dari discovery learning model adalah mengeksplorasi dan memecahkan masalah untuk menciptakan, menggabungkan dan menggeneralisasi pengetahuan, berpusat pada siswa, kegiatan untuk menggabungkan pengetahuan baru dan pengetahuan yang sudah ada (Maharani \& Hardini, 2017). Discovery learning model membiarkan siswa-siswa mengikuti minat mereka sendiri untuk mencapai kompeten dan kepuasan dari keingintahuan mereka. Guru sebaiknya mendorong siswa untuk menyelesaikan masalah-masalah mereka sendiri daripada mengajar mereka dengan jawaban-jawaban guru. Discovery learning bermanfaat dalam peningkatan potensi intelektual siswa, perpindahan dari pemberian reward ekstrinsik ke intrinsik, pembelajaran menyeluruh melalui proses menemukan, alat untuk melatih memori (Putra et al., 2017; Rahayu, 2019). Model ini digunakan untuk untuk mengembangkan cara belajar aktif dengan menemukan sendiri, menyelidiki sendiri, maka hasil yang akan diperoleh bertahan lama dalam ingatan sehingga tidak mudah dilupakan oleh siswa (Rahmayani, 2019; Setyowati et al., 2018). Discovery learning model menuntun siswa untuk mengidentifikasi apa yang ingin diketahui dengan mencari informasi sendiri, kemudian siswa mengorganisasi atau membentuk (konstruktif) apa yang diketahui dan dipahami ke dalam bentuk akhir (Rahmayani, 2019; Yuliana, 2019).

Selama ini sudah banyak penelitian mengenai discovery learning model, yang menjadikan penelitian ini berbeda dengan penelitian sebelumnya yaitu penerapan model pembelajaran yang dilaksanakan dalam bentuk daring menggunakan aplikasi google meet dan whatsapp, serta menayangkan powerpoint dan video pembelajaran yang dapat menguatkan pemahaman siswa mengenai materi yang dibelajarkan. Berdasarkan uraian di atas, maka perlu dilakukan penelitian tindakan kelas yang bertujuan untuk meningkatkan hasil belajar IPA dengan menerapkan discovery learning model berbantuan media powerpoint pada siswa kelas VI di SD No 8 Sumerta.

\section{METODE}

Penelitian ini menggunakan jenis penelitian tindakan kelas, yang merupakan penelitian yang digunakan untuk memperbaiki dan menyempurnakan sistem pembelajaran yang dilaksanakan oleh guru dalam suatu kelas (Susilowati, 2018). Penelitian tindakan kelas digunakan untuk memecahkan masalah yang terjadi pada pembelajaran di kelas. Melalui penerapan penelitian tindakan kelas pada kelas yang mengalami masalah akan dapat memperbaiki proses dan kualitas pembelajaran yang dilaksanakan di sekolah (Prihantoro \& Hidayat, 2019). Selain itu, penelitian tindakan kelas dapat digunakan karena penelitian ini dapat meningkatkan kemampuan guru dalam mengelola pembelajaran dan digunakan sebagai perbaikan kompetensi pengetahuan siswa terutama pada muatan materi IPA di sekolah dasar. Penelitian ini menggunakan tahapan kegiatan sesuai dengan rancangan dari penelitian tindakan kelas yang terdiri atas empat tahapan pada masing-masing siklusnya yaitu 1) perencanaan, 2) pelaksanaan, 3) observasi, dan 4) refleksi. Tahapan kegiatan pada setiap siklus pada disajikan seperti pada gambar 1. 


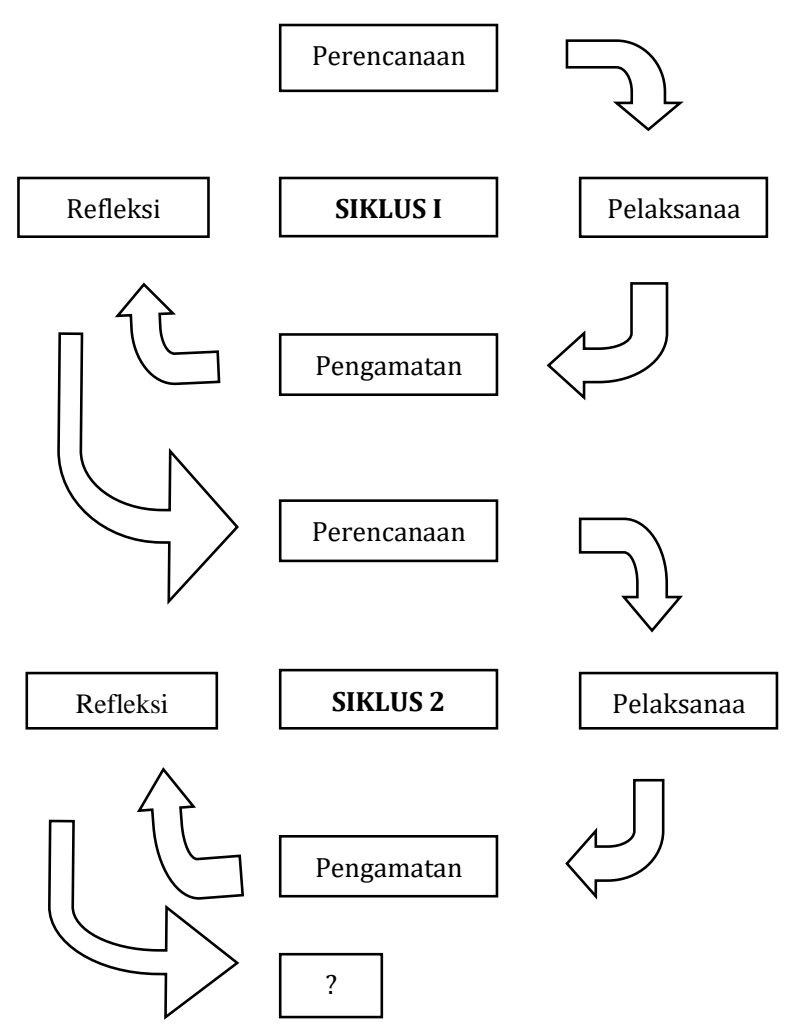

Gambar 1. Rancangan Penelitian Tindakan Kelas (Houtman, 2021)

Subjek penelitian ini adalah siswa kelas VI di SD No 8 Sumerta tahun ajaran 2020/2021. Jumlah siswa kelas VI yaitu berjumlah 33 siswa, yang terdiri dari 9 siswa laki-laki dan 24 siswa perempuan. Objek dalam penelitian ini adalah hasil belajar IPA siswa dengan menerapkan discovery learning model berbantuan media powerpoint. Penelitian ini menggunakan metode pengumpulan data yaitu metode tes. Metode tes akan digunakan untuk mengukur hasil belajar siswa IPA. Metode tes yang digunakan adalah pemberian post tes pada setiap akhir dari siklus. Post tes dilaksanakan sebanyak dua kali yaitu pada akhir siklus I dan post tes pada akhir siklus II. Pemberian post tes pada siklus I dan siklus II dilaksanakan setelah pertemuan ketiga dari proses pembelajaran pada setiap siklusnya. Adapun tujuan pemberian post tes pada akhir siklus yaitu untuk mengetahui hasil belajar IPA siswa setelah diberikan penerapan dengan menggunakan discovery learning model. Data dikumpulkan dengan instrumen penelitian berupa tes hasil belajar IPA yang dibagikan kepada semua siswa yang menjadi objek penelitian. Instrumen yang digunakan untuk pengumpulan data tentang hasil belajar IPA adalah tes hasil belajar dengan tes pilihan ganda. Butir pertanyaan pada tes hasil belajar berjumlah 20 soal. Tes ini mengungkapkan tentang penguasaan siswa terhadap pembelajaran IPA yang mereka peroleh di kelas VI pada ranah kognitif. Setiap soal disertai dengan empat alternatif jawaban yang dipilih oleh siswa (alternatif a, b, c, dan d) setiap item akan diberikan skor 1 bila siswa menjawab dengan benar (jawaban dicocokan dengan kunci jawaban) serta skor 0 untuk siswa yang menjawab salah, skor setiap jawaban kemudian dijumlahkan dan jumlah skor tersebut merupakan skor variabel hasil belajar IPA. Sebagai petunjuk kejelasan dari instrumen yang digunakan dalam post tes, diperlukan suatu kisi-kisi yang digunakan sebagai pedoman dalam penyusunan instrument. Adapun kisi-kisi instrument yang digunakan yaitu table 1.

Tabel 1. Kisi-kisi Instrumen Pos Test Siklus I dan Siklus II

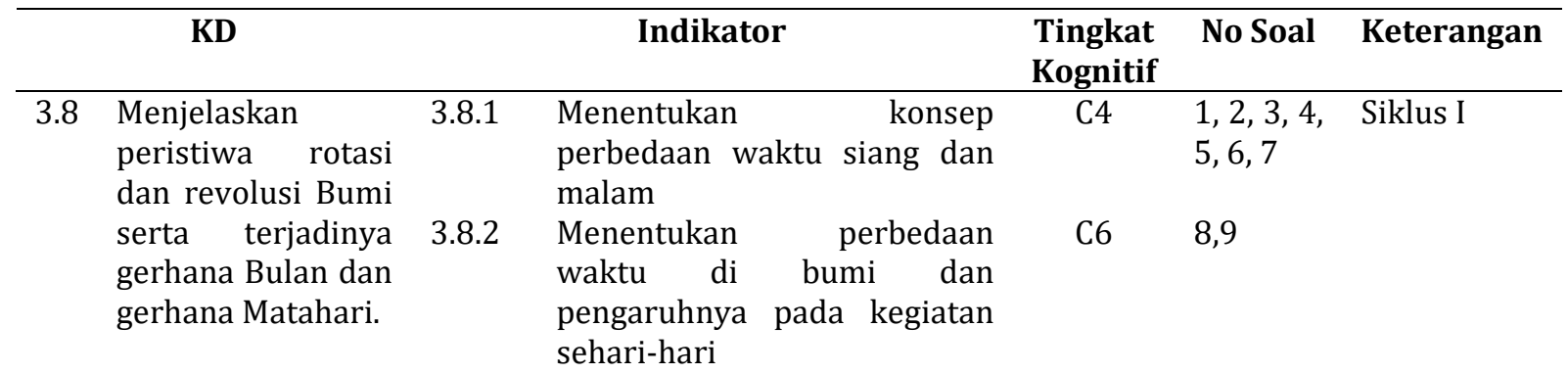




\begin{tabular}{|c|c|c|c|c|c|}
\hline \multirow[t]{2}{*}{ KD } & \multicolumn{2}{|r|}{ Indikator } & \multirow{2}{*}{$\begin{array}{c}\text { Tingkat } \\
\text { Kognitif } \\
\text { C4 }\end{array}$} & No Soal & \multirow[t]{2}{*}{ Keterangan } \\
\hline & 3.8 .3 & $\begin{array}{l}\text { Menganalisis penyebab } \\
\text { perbedaan waktu di bumi }\end{array}$ & & $\begin{array}{l}10, \quad 11, \\
12\end{array}$ & \\
\hline & 3.8 .4 & $\begin{array}{l}\text { Menganalisis peristiwa } \\
\text { revolusi bumi dan } \\
\text { dampaknya pada perubahan } \\
\text { musim di bumi }\end{array}$ & C4 & $\begin{array}{l}13,14 \\
15,16\end{array}$ & \\
\hline & 3.8 .5 & $\begin{array}{l}\text { Menentukan perbedaan } \\
\text { waktu pada setiap musim }\end{array}$ & C6 & $\begin{array}{l}17, \quad 18 \\
19,20\end{array}$ & \\
\hline & 3.8 .6 & $\begin{array}{l}\text { Menganalisis hal-hal yang } \\
\text { menyebabkan perbedaan } \\
\text { musim sebagai akibat dari } \\
\text { revolusi bumi }\end{array}$ & $\mathrm{C} 4$ & $1,2,3$ & Siklus II \\
\hline & 3.8 .7 & $\begin{array}{l}\text { Menentukan waktu terjadinya } \\
\text { musim kemarau dan musim } \\
\text { penghujan. }\end{array}$ & $\mathrm{C} 6$ & $4,5,6,7$ & \\
\hline & 3.8 .8 & $\begin{array}{l}\text { Menganalisis peristiwa rotasi } \\
\text { bulan }\end{array}$ & $\mathrm{C} 4$ & $8,9,10$ & \\
\hline & 3.8 .9 & $\begin{array}{l}\text { Menentukan pengaruh gerak } \\
\text { bulan pada bumi }\end{array}$ & C6 & $\begin{array}{l}11, \quad 12, \\
13\end{array}$ & \\
\hline & 3.8 .10 & $\begin{array}{l}\text { Menganalisis proses } \\
\text { terjadinya peristiwa gerhana } \\
\text { bulan }\end{array}$ & $\mathrm{C} 4$ & $\begin{array}{l}14, \quad 15, \\
16\end{array}$ & \\
\hline & 3.8 .11 & $\begin{array}{l}\text { Menentukan jenis gerhana } \\
\text { bulan dan penyebabnya }\end{array}$ & C6 & $\begin{array}{l}17, \quad 18, \\
19,20\end{array}$ & \\
\hline
\end{tabular}

Analisis data di dalam penelitian ini adalah menggunakan metode analisis deskriptif kuantitatif. Analisis deskriptif kuantitatif adalah suatu cara pengolahan data yang dilakukan dengan jalan sistematis dalam bentuk angka-angka dan atau persentase mengenai suatu objek yang diteliti (A. A. G. Agung, 2010). Untuk menentukan kualitas variabel-variabel tersebut, skor rata-rata (mean) tiap-tiap variabel dikonversikan dengan menggunakan daya serap dan keuntasan belajar serta indikator keberhasilan. Hasil analisis tingkat belajar siswa dapat ditentukan dengan rata-rata nilai siswa dan ketuntasan belajar yang dikonversikan ke dalam Penilaian Acuan Patokan (PAP) skala lima dengan berpedoman pada kriteria di tabel 2

Tabel 2. Kriteria Penilaian Acuan Patokan (PAP) skala lima

\begin{tabular}{cc}
\hline Tingkat penguasaan & Kategori \\
\hline $85 \%-100 \%$ & Sangat Tinggi \\
$70 \%-84 \%$ & Tinggi \\
$55 \%-69 \%$ & Cukup \\
$40 \%-54 \%$ & Rendah \\
$0-39 \%$ & Sangat Rendah \\
\hline
\end{tabular}

Pada penelitian ini siswa dikatakan tuntas jika tingkat penguasaan nilai rata-rata dan ketuntasan belajarnya masing-masing minimal mencapai skor 69. Sedangkan penelitian ini dikatakan berhasil apabila nilai rata-rata kelas, daya serap, dan ketuntasan kelas mencapai persentase tingkat penguasaan antara 70$84 \%$ dengan kriteria tinggi.

\section{HASIL DAN PEMBAHASAN}

Hasil belajar yang diperoleh dari pelaksanaan post tes pada siklus I dan siklus II dapat dipaparkan sebagai berikut. Berdasarkan hasil perolehan rata-rata persentase penguasaan kompetensi pengetahuan IPA pada siklus I adalah sebesar 67,57\%. Jika dikonversikan dalam tabel konversi PAP skala lima, angka tersebut menunjukkan bahwa penguasaan kompetensi pengetahuan IPA pada siklus I berada pada kriteria cukup. Hal tersebut menunjukkan bahwa penelitian penguasaan kompetensi pengetahuan IPA belum memenuhi kriteria keberhasilan yang ingin dicapai karena penguasaan kompetensi 
pengetahuan IPA masih berada pada kriteria cukup, sedangkan disarankan siswa mencapai kriteria penguasaan kompetensi pengetahuan IPA tinggi, oleh sebab itu penelitian dilanjutkan ke siklus berikutnya. Penguasaan kompetensi pengetahuan IPA siklus I, maka akan dilanjutkan ke siklus II dengan berpedoman pada hasil dari refleksi siklus I. Pelaksanaan penelitian tindakan kelas yang dilaksanakan pada siswa kelas VI SD No 8 Sumerta memperoleh beberapa temuan terkait dengan pembelajaran yang telah berlangsung. Tahap kegiatan yang dilakukan dalam penelitian tindakan kelas terdiri dari tahapan perencanaan, pelaksanaan, pengamatan, dan refleksi. Kemudian diperoleh beberapa temuan yang digunakan sebagai acuan untuk berlangsungnya kegiatan pembelajaran. Berdasarkan hasil pengamatan sebelum dilaksanakannya penelitian, terdapat masalah yang ditemukan terutama terkait dengan penguasaan kompetensi pengetahuan IPA siswa. Nilai ulangan muatan materi IPA siswa di akhir semester I menunjukkan sebanyak terdapat siswa belum memenuhi KKM.

Berdasarkan hasil temuan yang dilaksanakan pada saat prasiklus, maka diperlukan alternatif pemecahan yang digunakan sehingga siswa menjadi lebih aktif dalam pembelajaran serta terjadi peningkatan penguasaan kompetensi pengetahuan IPA siswa. Oleh sebab itu, alternatif yang digunakan adalah dengan penerapan discovery learning model. Model ini mengarahkan siswa untuk menemukan konsep melalui proses penemuan yang dilaksanakan, mengembangkan kemampuan siswa dalam membuat perencanaan, berkomunikasi, menyelesaikan masalah, dan membuat kesimpulan. Penerapan discovery learning model ini dilaksanakan dalam 2 siklus yang setiap siklus terdiri dari 4 kali pertemuan, yakni 3 kali pertemuan proses pembelajaran dan 1 kali pertemuan tes akhir siklus. Pada penelitian siklus I, instrumen penelitian yang digunakan adalah tes objektif dalam bentuk pilihan ganda biasa yang terdiri dari muatan materi IPA sebanyak 20 butir soal. Pembuatan soal disesuaikan dengan indikator dalam setiap pelaksanaan proses pembelajaran.

Pelaksanaan pembelajaran pada masing-masing siklus I telah berlangsung dengan baik. Hasil penelitian yang diperoleh melalui penerapan discovery learning model menunjukkan bahwa terjadi peningkatan pada hasil belajar IPA siswa. Hasil perolehan rata-rata persentase penguasaan kompetensi pengetahuan IPA siswa pada siklus I adalah sebesar $67,57 \%$. Hal tersebut menunjukkan bahwa penelitian penguasaan kompetensi pengetahuan IPA siswa belum memenuhi kriteria keberhasilan yang disarankan siswa mencapai kriteria penguasaan kompetensi pengetahuan IPA tinggi, sedangkan ketuntasan klasikal penguasaan kompetensi pengetahuan IPA siswa yaitu sebesar $66,66 \%$. Hasil tersebut belum mencapai ketuntasan klasikal yang disarankan adalah $\geq 80 \%$ memenuhi KKM $\geq 69$ yaitu berada pada rentang nilai 56-70 dengan predikat $C$ (cukup) sesuai pada standar kompetensi kelulusan. Berdasarkan data penguasaan kompetensi pengetahuan IPA siswa yang diperoleh belum mencapai kriteria yang disarankan, maka perlu adanya peningkatan dalam penelitian selanjutnya. Perbaikan merupakan upaya yang dilakukan untuk meningkatkan kualitas pembelajaran terutama untuk meningkatkan penguasaan kompetensi pengetahuan IPA siswa. Tindakan ini berpedoman kepada hasil pengamatan penelitian siklus I. Secara umum, kendala yang ditemukan pada siklus I yaitu keaktifan dalam proses pembelajaran kurang karena siswa masih merasa ragu-ragu dan malu untuk mengemukakan pendapat. Selain itu, pada saat proses pembelajaran berlangsung, beberapa siswa terlihat tidak konsentrasi dalam belajar. Berpijak dari permasalahan yang terjadi pada penelitian siklus I, maka diadakan perbaikan tindakan pada penelitian siklus II agar hasil belajar IPA siswa meningkat.

Data hasil belajar IPA siklus II diperoleh melalui pemberian tes pada akhir siklus II. Tes yang diberikan yaitu tes objektif berupa soal pilihan ganda sebanyak 20 butir. Hasil perolehan rata-rata hasil belajar IPA pada siklus II adalah sebesar 79,84. Jika dikonversikan dalam tabel konversi PAP skala lima, angka tersebut menunjukkan bahwa penguasaan kompetensi pengetahuan IPA pada siklus II berada pada kriteria tinggi. Hal tersebut menunjukkan bahwa penelitian penguasaan kompetensi pengetahuan IPA sudah memenuhi kriteria keberhasilan yang disarankan yaitu pada kriteria tinggi $(70 \%-84 \%)$, oleh sebab itu penelitian tidak dilanjutkan ke siklus berikutnya. Berdasarkan pada analisis data yang telah dilakukan, dapat diketahui mengenai persentase ketuntasan belajar IPA siswa siklus II yaitu 87,87\%. Oleh karena itu, dapat diperoleh hasil bahwa pelaksanaan tes akhir siklus II sudah mencapai indikator keberhasilan yang telah disarankan, yaitu mencapai kriteria tinggi atau persentase ketuntasan klasikal mencapai $\geq 80 \%$ siswa memenuhi KKM yaitu $\geq 69$ yaitu berada pada rentang nilai 56-70 dengan predikat C (cukup) sesuai pada standar kompetensi kelulusan. Pelaksanaan siklus II telah mencapai indikator keberhasilan yang disarankan sehingga tidak dilanjutkan ke siklus berikutnya. Pelaksanaan pembelajaran pada masing-masing siklus telah berlangsung dengan baik. Pelaksanaan pembelajaran yang baik ini ditandai dengan adanya peningkatan dari siklus I ke siklus II. Adapun hasil peningkatan dari siklus I ke siklus II dapat dilihat pada Tabel 3. 
Tabel 3. Rekapitulasi Hasil Belajar IPA pada Siklus I dan Siklus II

\begin{tabular}{ccc}
\hline Aspek & Siklus I & Siklus II \\
\hline Jumlah Siswa & 33 & 33 \\
Jumlah Nilai & 2230 & 2635 \\
KKM & 69 & 69 \\
Nilai Rata-rata & 67,57 & 79,84 \\
Nilai Tertinggi & 90 & 100 \\
Nilai Terendah & 45 & 60 \\
Jumlah siswa tuntas & 18 & 29 \\
Jumlah Siswa Tidak Tuntas & 15 & 4 \\
Persentase Ketuntasan Belajar Klasikal & $66,66 \%$ & $87,87 \%$ \\
\hline
\end{tabular}

Berdasarkan tabel 3, menunjukkan bahwa terjadinya peningkatan persentase rata-rata hasil belajar IPA siswa setelah menerapkan discovery learning model. Peningkatan rata-rata persentase hasil belajar IPA adalah 12,27\%, serta ketuntasan klasikal yang mengalami peningkatan sebesar 21,21\%. Berdasarkan data hasil belajar IPA siswa yang diperoleh pada tes akhir siklus I belum mencapai kriteria yang disarankan, maka perlu adanya peningkatan dalam penelitian selanjutnya. Perbaikan merupakan upaya yang dilakukan untuk meningkatkan kualitas pembelajaran terutama untuk meningkatkan hasil belajar IPA siswa. Tindakan ini berpedoman kepada hasil pengamatan penelitian siklus I. Secara umum, kendala yang ditemukan pada siklus I yaitu kestabilan sinyal saat proses pembelajaran melalui google meet tidak stabil, sehingga ketika siswa mendengarkan arahan dari guru tidak sepenuhnya dapat didengar dengan jelas. Penggunaan media powerpoint dalam pembelajaran sudah terlaksana namun tampilan slide show powerpoint tidak stabil karena sinyal yang kurang mendukung. Persentase kehadiran siswa pada saat pelaksanaan proses pembelajaran dengan menggunakan google meet cenderung berkurang ketika penyampaian hasil LKPD yang dibuat oleh siswa. Beberapa siswa tidak bisa mengikuti proses pembelajaran pada google meet, dikarenakan fasilitas HP yang digunakan masih bersama orang tua. Selain itu keaktifan dalam proses pembelajaran kurang karena siswa masih merasa ragu-ragu dan malu untuk mengemukakan pendapat. Pada saat proses pembelajaran berlangsung, beberapa siswa terlihat tidak konsentrasi dalam belajar. Hal ini dibuktikan dengan ketika siswa mengikuti proses pembelajaran yang dilaksanakan dengan google meet, ada orang tua siswa yang lewat dibelakang dan berbicara kepada siswa sehingga konsentrasi siswa menjadi terarah ke orang tuanya. Berpijak dari permasalahan yang terjadi pada penelitian siklus I, maka diadakan perbaikan tindakan pada penelitian siklus II agar hasil belajar IPA siswa meningkat.

Berdasarkan hasil pembelajaran pada siklus II, terdapat beberapa temuan dalam proses pembelajaran yaitu siswa sudah berani mengangkat tangan untuk mengemukakan pendapatnya ataupun bertanya mengenai permasalahan yang dihadapi. Waktu pelaksanaan proses pembelajaran melalui google meet dipidahkan ke sore hari, agar semua siswa bisa mengikuti proses pembelajaran. Siswa melaksanakan proses pembelajaran didalam ruangan sehingga konsentrasi siswa lebih terfokus ketika belajar. Guru melaksanakan ice breaking agar siswa tidak bosan ketika belajar. Pada proses pembelajaran, kondisi pembelajaran dengan google meet sangat kondusif karena siswa sudah memperhatikan dengan baik ketika guru menjelaskan. Penggunaan media powerpoint dan metode dalam membuat siswa menjadi antusian dalam belajar, karena media powerpoint dan metode mengajar tersebut dapat digunakan untuk merangsang pikiran, perasaan, perhatian dan kemauan siswa sehingga dapat mendorong terjadinya proses belajar pada siswa (Nasution, 2017; Pramestika, 2020). Secara umum, pelaksanaan pembelajaran pada siklus II telah berlangsung sesuai dengan perencanaan sehingga indikator, tujuan pembelajaran, dan penguasaan kompetensi pengetahuan siswa tercapai dengan optimal.

Berdasarkan hasil dan pembahasan pada penelitian, dapat disimpulkan bahwa adanya peningkatan hasil belajar IPA siswa kelas VI melalui penerapan discovery learning model berbantuan media powerpoint, hal ini disebabkan oleh beberapa faktor yaitu dapat dijelaskan sebagai berikut. Pertama penerapan discovery learning model dalam pembelajaran. Discovery learning merupakan nama lain dari pembelajaran penemuan. Sesuai dengan namanya, model ini mengarahkan siswa untuk dapat menemukan sesuatu melalui proses pembelajaran yang dilakoninya guna mengembangkan cara belajar aktif dengan menemukan sendiri, menyelidiki sendiri, sehinggan maka hasil yang akan diperoleh bertahan lama dalam ingatan sehingga tidak mudah dilupakan oleh siswa (Nugrahaeni, 2019; Maharani \& Hardini, 2017). Siswa diharapkan untuk terbiasa menjadi seorang saintis (ilmuan). Mereka tidak hanya sebagai konsumen, tetapi diharapkan pula bisa berperan aktif, bahkan sebagai pelaku dari pencipta ilmu pengetahuan. Siswa dalam proses pembelajaran menggunakaan discovery learning model maka mampu berpikir analisis dan mencoba memecahkan sendiri masalah yang dihadapi sehingga penerapan discovery learning model ini sangat cocok diterapkan pada muatan IPA (Hannya \& Kristin, 2020). Pembelajaran 
discovery learning merupakan metode pembelajaran pengetahuan yang menuntut guru untuk dapat lebih kreatif dalam menciptakan situasi yang dapat membuat peserta didik belajar aktif menemukan pengetahuan sendiri (Sani, 2014). Penggunaan discovery learning model dimaksudkan untuk merubah kondisi belajar yang pasif menjadi aktif dan kreatif, mengubah pembelajaran yang teacher oriented ke student oriented, mengubah modus ekspository peserta didik hanya menerima informasi secara keseluruhan dari guru ke modus discovery peserta didik menemukan informasi sendiri (Dari \& Ahmad, 2020).

Kedua adanya media pembelajaran dimana media digunakan sebagai alat bantu proses belajar mengajar yang dapat dipergunakan untuk merangsang pikiran, perasaan, perhatian dan kemampuan atau ketrampilan pembelajar (Niswatuzzahro et al., 2018). Penggunaan media dalam kegiatan belajar mengajar, terutama untuk tingkat sekolah dasar sangat penting, karena pada masa ini siswa masih berpikir konkret, dan belum mampu berpikir abtrak. Kehadiran media sangat membantu mereka dalam memahami konsep tertentu yang kurang mampu dijelaskan dengan bahasa. Ketidak kemampuan guru menjelaskan sesuatu bahan itulah dapat diwakili oleh peranan media. Pemanfaatan powerpoint dalam proses pembelajaran menyebabkan kegiatan pembelajaran menjadi sangat mudah, dinamis dan sangat menarik (Khaerunnisa et al., 2018). Selain itu, media pembelajaran dapat bermanfaat dalam proses belajar mengajar yaitu media pembelajaran dapat memperjelas penyajian, dan menarik perhatian siswa, untuk meningkatkan proses dan hasil belajar, menimbulkan motivasi belajar, mengatasi keterbatasan indera, ruang, dan waktu, dan memberikan kesamaan pengalaman kepada siswa (Damitri \& Adista, 2020). Media pembelajaran dapat dimanfaatkan sebagai alat komunikasi dalam proses belajar mengajar agar pesan yang disampaikan oleh guru mudah untuk dipahami.

Ketiga lebih lanjut, adanya peningkatan hasil belajar yang memuncul dari perubahan tingkah laku. Perubahan tingkah laku yang dimaksud merupakan hasil dari proses belajar ini dilakukan dengan menggunakan sintaks dari discovery learning model. Terdapat tujuh langkah sintaks discovery learning model yaitu pemberian stimulus, identifikasi masalah, pengumpulan data, pengolahan data, pembuktian, dan menarik kesimpulan (Yuliana, 2019). Kegiatan pembelajaran yang dilaksanakan pada setiap sintaks menimbulkan adanya perbedaan antara aktivitas guru dengan siswa. Siswa didorong untuk memiliki rasa ingin tahu, pengalaman belajar, keaktifan melalui kegiatan pengolahan data, pembuktian hingga akhirnya siswa mampu menarik suatu kesimpulan (Astuti et al., 2018). Setiap siswa yang belajar dengan mengunakan discovery learning model mendapatkan suatu pengalaman belajar langsung, konsep baru serta siswa membuat penalaran atas sesuatu yang telah diketahui dan apa yang dibutuhkan dalam pengalaman belajar (Izetbigovic et al., 2019). Proses belajar akan berjalan dengan baik dan kreatif jika guru memberikan kesempatan kepada peserta didik untuk menemukan suatu konsep, teori, aturan, atau pemahaman melalui contoh-contoh yang ia jumpai dalam kehidupannya. Sehingga belajar tidak hanya penguasaan konsep teori mata pelajaran saja, tetapi juga penguasaan kebiasaan, persepsi, kesenangan, minat-bakat, penyesuaian sosial, keterampilan, keinginan dan harapan sehingga muncul motivasi dalam belajar yang akan mempengaruhi hasil belajar siswa (Putri et al., 2017).

Penemuan ini juga diperkuat oleh penelitian sebelumnya yang menyatakan discovery learning model berpengaruh terhadap kompetensi pengetahuan IPA siswa kelas VI SD Gugus Yos Sudarso Kecamatan Denpasar Selatan (A. Agung et al., 2017). Penerapan metode discovery learning dapat secara efektif diterapkan dalam kegiatan pembelajaran PAI (Kurniati, 2016). Penerapan discovery learning model dapat meningkatkan kemampuan berpikir kreatif dan hasil belajar pembelajaran Tematik siswa kelas $\mathrm{V}$ (Rahmayani, 2019). Media pembelajaran powerpoint efektif meningkatkan hasil belajar biologi (Srimaya, 2017).

Penelitian ini memiliki beberapa kelebihan yaitu pembelajaran dilaksanakan secara daring dengan menggunakan google meet dan whatapps serta adanya penggunaan media powerpoint. Penelitian ini berimplikasi terhadap penerapan discovery learning model berbantuan media powerpoint, yaitu siswa berperan aktif memecahkan berbagai persoalan yang dihadapi, pengalaman langsung saat belajar, keterlibatan siswa secara aktif dalam proses pembelajaran, pembelajaran bersifat konstruktivisme, peningkatkan daya ingat siswa dan pembelajaran berpusat pada siswa. Implikasi tersebut tentu masih memiliki beberapa kekurangan karena adanya keterbatasan dalam penelitian ini. Maka diperlukan adanya rekomendasi pada penelitian berikutnya yang berkaitan dengan pembelajaran dengan discovery learning model.

\section{SIMPULAN}

Penerapan model pembelajaan discovery learning berbantuan media powerpoint dapat meningkatkan hasil belajar IPA. Berdasarkan temuan dalam penelitian ini, dapat disampaikan saran kepada peneliti lain yang berminat mengadakan penelitian yang berkaitan dengan discovery learning 
model agar memperhatikan kekurangan dan kendala yang dialami dalam penelitian ini sebagai bahan pertimbangan untuk perbaikan serta penyempurnaan penelitian yang akan dilaksanakan dan discovery learning model diharapkan dapat diterapkan pada jenjang dan muatan pembelajaran yang berbeda

\section{DAFTAR RUJUKAN}

Agung, A. A. G. (2010). Pengantar Evaluasi Pendidikan. Fakultas Ilmu Pendidikan Undiksha.

Agung, A., Trisna, B., Candra, A., Sujana, I. W., \& Ardana, I. K. (2017). "Pengaruh Discovery learning model Terhadap Kompetensi Pengetahuan IPA Siswa Kelas VI Denpasar Selatan Tahun Pelajaran 2016/2017." Mimbar PGSD Undiksha, 5(2), 1-10. https://doi.org/http://dx.doi.org/10.23887/jjpgsd.v5i2.10655.

Agustami, R. P., Alimah, S., \& Artikel, I. (2017). Persepsi Guru dan Siswa Terhadap Pembelajaran IPA Terpadu Serta Implikasinya di SMP. Journal of Innovative Science Education, 6(1), 96-103. https://doi.org/10.15294/jise.v6i1.17069.

Amallia Nugrahaeni, I Wayan Redhana, I. M. A. K. (2019). Penerapan Discovery learning model Untuk Meningkatkan Kemampuan Berpikir Kritis Dan Hasil Belajar Kimia. Jurnal Basicedu, 3(1), 21-26. https://doi.org/10.31004/basicedu.v3i1.62.

Astuti, T. I., Idrus, I., \& Yennita, Y. (2018). Penerapan Discovery learning model Untuk Meningkatkan Hasil Belajar Pada Materi Biologi Siswa Smp. Diklabio: Jurnal Pendidikan Dan Pembelajaran Biologi, 2(1), 5-9. https://doi.org/10.33369/diklabio.2.1.5-9.

Awe, E. Y., \& Benge, K. (2017). Hubungan Antara Minat Dan Motivasi Belajar Dengan Hasil Belajar Ipa Pada Siswa Sd. Journal of Education Technology, 1(4), 231. https://doi.org/10.23887/jet.v1i4.12859.

Damitri, D. E., \& Adista, G. A. Y. P. (2020). Keunggulan Media Powerpoint Berbasis Audio Visual Sebagai Media Presentasi Terhadap Hasil Belajar Siswa Smk Teknik Bangunan. Jurnal Pendidikan Teknik Bangunan, 6(2), 1-7. https://ejournal.unesa.ac.id/index.php/jurnal-kajian$\mathrm{ptb} /$ article/view/36296.

Dari, F. W., \& Ahmad, S. (2020). Discovery learning model Sebagai Upaya Meningkatkan Kemampuan Berpikir Kritis Siswa SD. Jurnal Pendidikan Tambusai, 4(2014), 1469-1479. https://doi.org/https://doi.org/10.31004/jptam.v4i2.612.

Eviani, Sri Utami, T. S. (2017). Pengaruh Model Pembelajaran Berbasis Masalah Terhadap Kemampuan Literasi Sains IPA Kelas V SD. Skripsi Pendidikan Biologi, 05(1), 1-8. https://training.unmuhkupang.ac.id/index.php/jpdf/article/view/139.

Frandy Pratama, Firman, N. (2010). Pengaruh Motivasi Belajar Ipa Siswa Terhadap Hasil Belajar Di Sekolah Dasar Negeri 01. Edukatif: Jurnal Ilmu Pendidikan, 1(3), 280-286. https://doi.org/https://doi.org/10.31004/edukatif.v1i3.63.

Hannya, \& Kristin, F. (2020). Meta Analisis Penggunaan Discovery learning model Dalam Meningkatkan Hasil Belajar IPA Siswa SD. Ilmiah Pendidikan Dan Pembelajaran, 4(3), 529-536. https://doi.org/http://dx.doi.org/10.23887/jipp.v4i3.29462.

Houtman, H. (2021). Pelatihan Penyusunan Proposal Penelitian Tindakan Kelas Di Man 1 Musi Banyuasin. KENDURI: Jurnal Pengabdian Dan Pemberdayaan ..., 01(01), 16-21. https://www.siducat.org/index.php/kenduri/article/view/171.

Hujaemah, E., Saefurrohman, A., \& Sultan Maulana Hasanuddin Banten, U. (2015). Pengaruh Penerapan Model Snowball Throwing Terhadap Hasil Belajar Ipa Di Sekolah Dasar. Terbit Sejak, 5(1), 23-32. https://doi.org/http://dx.doi.org/10.31602/muallimuna.v5i1.2203.

I Putu Ari Sudana, I. G. A. W. (2018). Penerapan Model Pembelajaran Kooperatif Tipe Stad Untuk Meningkatkan Hasil Belajar IPA. Primary: Jurnal Pendidikan Guru Sekolah Dasar, 7(1), 178. https://doi.org/10.33578/jpfkip.v7i1.5359.

Ichsan, I. Z., Dewi, A. K., Hermawati, F. M., \& Iriani, E. (2018). Pembelajaran IPA dan Lingkungan: Analisis Kebutuhan Media Pembelajaran pada SD, SMP, SMA di Tambun Selatan, Bekasi. JIPVA Jurnal Pendidikan IPA Veteran), 2(2), 131. https://doi.org/10.31331/jipva.v2i2.682.

Izetbigovic, M. A., Solfarina, , \& Langitasari, I. (2019). Penerapan Discovery learning model untuk Meningkatkan Keterampilan Generik Sains Siswa. EduChemia (Jurnal Kimia Dan Pendidikan), 4(2), 164. https://doi.org/10.30870/educhemia.v4i2.6118.

Johana Ermina Setyaningtyas, Firosalia Kristin, I. A. (2018). Peningkatan Kreativitas Dan Hasil Belajar Mata Pelajaran Ipa Menggunakan Model Pembelajaran Quantum Teaching Pada Siswa Kelas 2. Jurnal Mitra Pendidikan, 2(6), 530. http://www.e-jurnalmitrapendidikan.com/index.php/ejmp/article/view/737/473.

Juita, R. (2019). Meningkatkan Hasil Belajar IPA Melalui Metode Eksperimen Pada Siswa Kelas IV SDN 02 Kota Mukomuko. IJIS Edu: Indonesian Journal of Integrated Science Education, 1(1), 43. 
https://doi.org/10.29300/ijisedu.v1i1.1404.

Jundu, R., Tuwa, H., \& Seliman, R. (2013). Hasil Belajar IPA Siswa SD di Daerah Tertinggal dengan Penerapan Model Pembelajaran Inkuiri Terbimbing. 103-111. https: //doi.org/https://doi.org/10.24246/j.js.2020.v10.i2.p103-111.

Khaerunnisa, F., Sunarjan, Y., \& Atmaja, H. T. (2018). Pengaruh Penggunaan Media Powerpoint Terhadap Minat Belajar Sejarah Siswa Kelas X SMA Negeri 1 Bumiayu Tahun Ajaran 2017/2018 Febriana. Indonesian Journal of History Education, 6(1), 31-41. https: //journal.unnes.ac.id/sju/index.php/ijhe/article/view/27352.

Kurniati, A. (2016). Pengembangan Modul Matematika Berbasis Kontekstual Terintegrasi Ilmu Keislaman. Al-Khwarizmi: Jurnal Pendidikan Matematika Dan Ilmu Pengetahuan Alam, 4(1), 43-58. https: //doi.org/10.24256/jpmipa.v4i1.251.

Kusumah, R. G. T., Walid, A., Pitaloka, S., Dewi, P. S., \& Agustriana, N. (2020). Penerapan Metode Inquiry Sebagai Usaha Untuk Meningkatkan Hasil Belajar Ipa Pada Materi Penggolongan Hewan Di Kelas Iv Sd Seluma. Jurnal Pendidikan Matematika Dan IPA, 11(1), 142-153. https://doi.org/10.26418/jpmipa.v11i1.34708.

Maharani, B. Y., \& Hardini, A. T. A. (2017). Penerapan Discovery learning model Berbantuan Benda Konkret Untuk Meningkatkan Hasil Belajar Ipa. E-Jurnalmitrapendidikan, 1(5), 549-561. http://ejurnalmitrapendidikan.com/index.php/e-jmp/article/view/106.

Muyaroah, S. (2018). Efektifitas Model Pembelajaran Inside Outside Cirle Terhadap Hasil Belajar Siswa Pada Mata Pelajaran Ipa Sd Fransiskus Baturaja. Pedagogia, 16(2), 99. https://doi.org/10.17509/pdgia.v16i2.12052.

Nasution, M. K. (2017). Penggunaan metode pembelajaran dalam peningkatan hasil belajar siswa. STUDIA DIDAKTIKA: Jurnal Ilmiah Bidang Pendidikan, 11(1), 9-16. http://www.jurnal.uinbanten.ac.id/index.php/studiadidaktika/article/view/515.

Ni Kt. Dewi Muliani, I. M. C. W. (2019). Pengaruh Model Pembelajaran Inkuiri Terbimbing Berbantuan Video Terhadap Hasil Belajar IPA. Jurnal Ilmiah Sekolah Dasar, 3(1), 1-10. https: //doi.org/10.31539/spej.v2i1.333.

Niswatuzzahro, V., Fakhriyah, F., \& Rahayu, R. (2018). Penerapan Discovery learning model Berbantuan Media Audio Visual untuk Meningkatkan Literasi Sains Siswa Kelas 5 SD. Scholaria: Jurnal Pendidikan Dan Kebudayaan, 8(3), 273-284. https://doi.org/10.24246/j.js.2018.v8.i3.p273-284.

Nugroho Widiantono, N. H. (2017). Penerapan Model Pembelajaran Interaktif Untuk Meningkatkan Aktivitas Dan Hasil Belajar IPA Siswa Kelas 5SD. Scholaria : Jurnal Pendidikan Dan Kebudayaan, 1, 199-213. https://doi.org/https://doi.org/10.24246/j.scholaria.2017.v7.i3.p199-213.

Nuraini, F., \& Kristin, F. (2017). Penggunaan Model Problem Based Learning (Pbl) Untuk Meningkatkan Hasil Belajar Ipa Siswa Kelas 5 Sd. E-Jurnalmitrapendidikan, 1(4), 369-379. https: //doi.org/10.1080/10889860091114220.

Nurrohmi, Y., Utaya, S., \& Utomo, D. H. (2017). Pengaruh Discovery learning model Terhadap Kemampuan Berpikir Kritis. Jurnal Pendidikan, 2(1), 1308-1314. https://doi.org/http://dx.doi.org/10.17977/jptpp.v2i10.10062.

Oktaviani, W., Kristin, F., \& Anugraheni, I. (2019). Penerapan Discovery learning model Untuk Meningkatkan Kemampuan Berpikir Kritis Dan Hasil Belajar Matematika Siswa Kelas 5 SD. Jurnal Basicedu, 3(2), 524-532.

Portanata, L., Lisa, Y., \& Awang, I. S. (2017). Analisis Pemanfaatan Media Pembelajaran IPA SD. Jurnal Pendidikan Dasar PerKhasa, 341), 348. https://doi.org/https://doi.org/10.31932/jpdp.v3i1.53.

Pramestika, L. A. (2020). Efektifitas Penggunaan Media Powerpoint Terhadap Hasil Belajar Matematika Materi Bangun Datar dan Bangun Ruang SD. Jurnal Pendidikan Dan Konseling, 2(1), 110-114. https://journal.universitaspahlawan.ac.id/index.php/jpdk/article/view/610/516.

Prasetyo, F., \& Kristin, F. (2020). Pengaruh Model Pembelajaran Problem Based Learning dan Discovery learning model terhadap Kemampuan Berpikir Kritis Siswa Kelas 5 SD. DIDAKTIKA TAUHIDI: Jurnal Pendidikan Guru Sekolah Dasar, 7(1), 13. https://doi.org/10.30997/dt.v7i1.2645.

Prihantoro, A., \& Hidayat, F. (2019). Melakukan Penelitian Tindakan Kelas. Ulumuddin : Jurnal Ilmu-Ilmu Keislaman, 9(1), 49-60. https://doi.org/10.47200/ulumuddin.v9i1.283.

Putra, K. W. B., Wirawan, I. M. A., \& Pradnyana, G. A. (2017). Pengembangan E-Modul Berbasis Discovery learning model Pada Mata Pelajaran "Sistem Komputer" Untuk Siswa Kelas X Multimedia Smk Negeri 3 Singaraja. Jurnal Pendidikan Teknologi Dan Kejuruan, 14(1), 40-49. https: //doi.org/10.23887/jptk.v14i1.9880.

Putra, P. (2017a). Pendekatan Etnopedagogi dalam Pembelajaran IPA SD / MI. Primary Education Journal (PEJ), 1(1), 17-23. http://pej.ftk.uinjambi.ac.id/index.php/PEJ/article/view/1. 
Putra, P. (2017b). Penerapan Pendekatan Inkuiri Pada Mata Pelajaran IPA untuk Mengembangkan Karakter Siswa di SDN 01 Kota Bangun. Muallimuna, 3(1), 28-47. https://doi.org/http://dx.doi.org/10.31602/muallimuna.v3i1.953.

Putri, R. H., Lesmono, A. D., \& Aristya, P. D. (2017). Pengaruh Model Discovery Terhadap Motivasi Belajar Dan Hasil Belajar Fisika Siswa Man Bondowoso. Jurn.al Pembelajaran Fisika, 6(2), 168-174. https://doi.org/https://doi.org/10.19184/jpf.v6i2.5017.

Rahmayani, A. L. (2019). Pengaruh Discovery learning model dengan Menggunakan Media Video Terhadap Hasil Belajar Siswa. Jurnal Pendidikan (Teori Dan Praktik), 4(1), 59. https://doi.org/10.26740/jp.v4n1.p59-62.

Ratih Dwi Yulianti Rahayu, Mawardi, S. A. (2019). Peningkatan Keterampilan Berpikir Kritis dan Hasil Belajar Siswa Kelas 4 SD melalui Discovery learning model. Jurnal Penelitian Pendidikan IPA, 4(1), 8-13. https://doi.org/10.29303/jppipa.v1i2.20.

Sani, R. A. (2014). Pembelajaran Saintifik untuk Implementasi Kurikulum 2013. PT. Bumi Aksara.

Sappe, I., Ernawati, E., \& Irmawanty, I. (2018). Hubungan Motivasi Belajar terhadap Hasil Belajar Ipa Siswa Kelas V sdn 231 Inpres Kapunrengan Kecamatan Mangarabombang Kabupaten takalar. JKPD (Jurnal Kajian Pendidikan Dasar), 3(2), 530. https://doi.org/10.26618/jkpd.v3i2.1419.

Setyowati, E., Kristin, F., \& Anugraheni, I. (2018). Penggunaan Discovery learning model Untuk Meningkatkan Kreativitas Dan Hasil Belajar Siswa Kelas 5 Sd Negeri Mangunsari 07. Justek : Jurnal Sains Dan Teknologi, 1(1), 76. https://doi.org/10.31764/justek.v1i1.408.

Sitohang, J. (2017). Penerapan Metode Tanya Jawab untuk Meningkatkan Hasil Belajar IPA Pada Siswa Sekolah Dasar. Suara Guru : Jurnal Ilmu Pendidikan Sosial, Sains, Dan Humaniora, 3(4), 681-688. https://doi.org/http://dx.doi.org/10.24014/suara\%20guru.v3i4.4851.

Srimaya. (2017). Efektivitas Media Pembelajaran Powerpoint Untuk Meningkatkan Motivasi Dan Hasil Belajar Biologi Siswa. Jurnal Biotek Volume 5 Nomor 1 Juni 2017, 5(1), 53-68. https://doi.org/https://doi.org/10.24252/jb.v5i1.3446.

Supardi, K. (2017). Media Visual Dan Pembelajaran Ipa. Jurnal Inovasi Pendidikan Dasar, 1(10). http://unikastpaulus.ac.id/jurnal/index.php/jipd/article/vie.w/266.

Surya, Y. F. (2017). Penerapan Metode Eksperimenuntuk Meningkatkan Hasil Belajar IPA Siswa Kelas IV Sdn 011 Langgini Kabupaten Kampar. Jurnal Basicedu, 1(1), 10-20. https://doi.org/10.31004/basicedu.v1i1.150.

Susilowati, D. (2018). Penelitian Tindakan Kelas (Ptk) Solusi Alternatif Problematika Pembelajaran. Jurnal Ilmiah Edunomika, 2(01), 36-46. https://doi.org/10.29040/jie.v2i01.175.

Tias, I. W. U. (2017). Penerapan Model Penemuan Terbimbing Untuk Meningkatkan Hasil Belajar Ipa Siswa Sekolah Dasar. DWIJA CENDEKIA: Jurnal Riset Pedagogik, 1(1), 50-60. https://doi.org/10.20961/jdc.v1i1.13060.

Wahyuningtyas, R., \& Sulasmono, B. S. (2020). Pentingnya Media dalam Pembelajaran Guna Meningkatkan Hasil Belajar di Sekolah Dasar. Edukatif: Jurnal Ilmu Pendidikan, 2(1), 23-27. https://doi.org/10.31004/edukatif.v2i1.77.

Winantara, I. W. D. (2017). Penerapan Model Pembelajaran Tps Untuk Meningkatkan Hasil Belajar Ipa Siswa Kelas V Sd No 1 Mengwitani. Journal of Education Action Research, 1(2), 148. https://doi.org/10.23887/jear.v1i2.12047.

Yuliana, N. (2019). Penggunaan Discovery learning model Dalam Peningkatan Hasil Belajar Siswa Di Sekolah Dasar. Jurnal Ilmiah Pendidikan Dan Pembelajaran, 18(2), 56. https://doi.org/10.24036/fip.100.v18i2.318.000-000. 